\title{
Optimization of Renewable Energy Production by Utilizing Methane Gas And plastic waste from sources at the Puuwatu landfill Kendari City
}

\author{
Yuspian Gunawan ${ }^{1)}$, La Karimuna ${ }^{2)}$, Lukas Kano M. ${ }^{3)}$, Nanang Endriatno ${ }^{4)}$ \\ 1) Department of Mechanical Engineering, Faculty of Engineering, Halu Oleo University, Indonesia \\ 2) Department of Agriculture, Faculty of Agriculture, Halu Oleo University, Indonesia \\ 3), 4) Department of Mechanical Engineering, Faculty of Engineering, Halu Oleo University, Indonesia
}

\begin{abstract}
This study aims to determine how much electric power can be generated from methane gas obtained from organic waste and how much electrical energy has not been utilized from the potential methane gas produced and how much volume of pyrolysis oil is produced from plastic waste produced by the people of the City. Kendari. To obtain the electrical energy produced, the volume of waste is first calculated so that the potential for waste (Q), Biogas Production Volume (VBS), and Methane Gas Volume (VGM) can be obtained. Referring to Kadir's research, 2012, the volume of pyrolysis oil produced by Kendari City is obtained. The results showed that the energy produced from the Puuwatu TPA in a daily average was $288,466,5332 \mathrm{kWh}$. While the energy flowing through the Mandirin Energi area is 125 houses and each house with a power of $450 \mathrm{VA}$ (MCB 2 Ampere), the daily count used to fulfill the energy independent area is $1,080 \mathrm{kWh}$, so that energy has not been utilized from its potential. in Puuwatu TPA is 287,386.5332 kWh. While the production of plastic waste in Kendari City per year is 792 tons, the average plastic waste produced in 500 grams is $423.25 \mathrm{ml}$ of pyrolysis oil or the equivalent of 1000 grams produces pyrolysis oil of 845.6 milliliters, so the amount of plastic waste in Kendari City per year year it can produce pyrolysis oil of 670428000 liters.
\end{abstract}

Keywords: Organic Waste, Methane Gas, Electrical Energy, Pyrolysis Oil, Plastric Waste.

\section{Background}

Kendari city with a population in 2017 of 335,899, covering 28,541 households (Based on data from the 2017 Statistics Agency) / (BPS). With a population density of 54 people / $\mathrm{km} 2$, it will produce a large volume of waste. With this population, Kendari City waste generation can be assumed by using a theoretical approach factor, namely as much as $763,326 \mathrm{~m} 3$ per day with a waste weight of $150,000.15 \mathrm{~kg}$ of garbage / day or the same as 150 tons of waste per day. Of the volume of waste generation, about $50 \%$ to $75 \%$ is organic waste (wet waste) and the rest is inorganic waste (dry waste) which, if properly managed, can be recycled or reused as alternative energy, one of which is by using the plastic waste pyrolysis process for produce pyrolysis oil.

\section{Theoretical Basis}

Waste management
Human activities produce waste materials that are often discarded because they are deemed useless. This waste is usually solid, and the word waste indicates that the material is useless and unwanted. However, much of this waste material is reusable, so it can become a resource for industrial production or energy generation, if managed properly. Waste management has become one of the most significant problems of our time because the way of life now produces large amounts of waste, and most people want to maintain their lifestyle, while protecting the environment and public health. Industry, private citizens, and state legislators are looking for ways to reduce the growing amount of waste dumped by American homes and businesses and to reuse or dispose of it safely and economically. In recent years, state legislatures have passed more laws governing solid waste management than any other topic on their legislative agendas. [1] 
Waste management is a complex process because it involves many technologies and scientific disciplines. This includes technologies related to the control of generation, handling, storage, collection, transfer, transportation, processing and disposal of solid waste. Figure 1.2). All of these processes must be carried out within existing legal and social guidelines that protect public health and the environment and are aesthetically and economically acceptable. In order for the disposal process to respond to public attitudes, the disciplines to consider include administrative, financial, legal, architectural, planning, and engineering functions. All of these disciplines must communicate and interact with each other in positive interdisciplinary relationships for an integrated solid waste management plan to be successful. [1]

The per capita rate was around 4.6 pounds per person per day and an overall rate of 240 million tonnes per year in 2005. Although waste reduction and recycling now play an important role in management, these management options alone cannot solve the solid waste problem. Assuming a recycling rate (diversion) of about 50 percent can be done, more than 120 million tonnes of solid waste will still have to be treated in other ways, such as incineration (waste into energy) and landfill. [1]

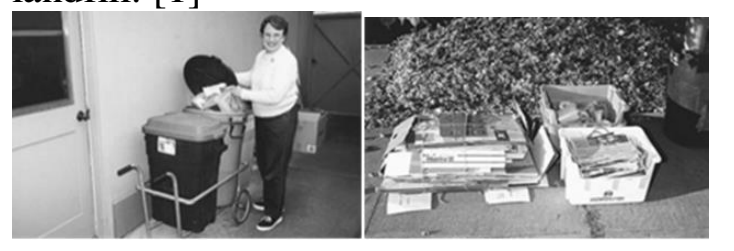

a

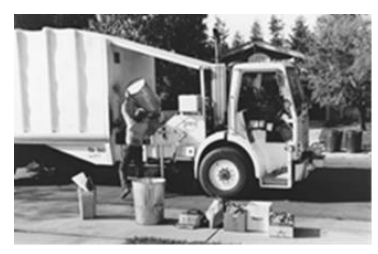

C

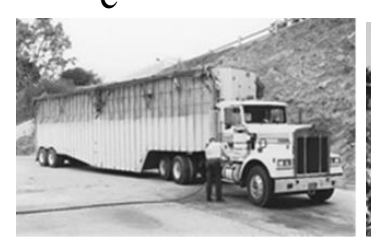

e b

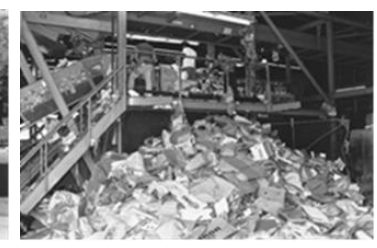

d

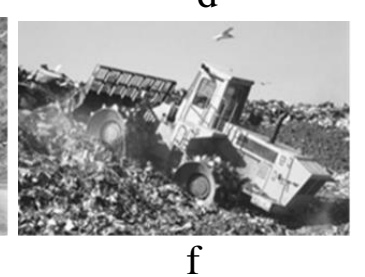

Figure 2.1 Views of the functional activities that comprise a solid waste management system: (a) waste gen- eration; (b) waste handling and separation, storage, and processing at the source; (c) collection; (d) separation, processing, and transformation of solid waste; (e) transfer and transport; and (f) disposal. [1]

\section{Energy}

In 2010, many countries have realized the importance of utilizing Renewable Energy sources as a substitute for non-renewable energy such as oil, coal and gas which has had a very destructive impact on the earth. With the depletion of reserves for non-renewable energy sources, the cost of mining them will increase, which has an impact on increasing the selling price to the community. At the same time, non-renewable energy will release carbon emissions into the atmosphere, which is a big contributor to global warming. [2

The level of exploitable resources, of course, depends on the price consumers are willing to pay, so any discussion of the resource base is inseparable from assumptions about the price level. The characteristic of renewable sources, like other energy sources, is that they have a smaller technical resource base and economic base, which increases in size towards a technical basis as energy prices increase. The summary here will be limited to renewable resources available in the UK at costs quoted in 1987 terms using a 5\% test discount rate unless otherwise stated. It is easy to gauge the potential contribution to energy supply especially in terms of UK demand for electric power and energy, which in 1987 was $52 \cdot 5 \mathrm{GW}$ and $256 \mathrm{TWh}$ maximum demand respectively. In addition to providing an overview of the costs in each section, this report provides an overview of the cost of electricity generation based on independent surveys and analysis of the results presented in full. [3]

Renewable energy sources can reduce pollution by replacing conventional thermal generators in the electricity supply. In practice, the anticipated slow use of renewable technologies will have no significant impact on reducing pollution over the next few decades unless government policies enforce such measures. Renewable energies can have their own environmental impacts, however, visual disturbances, noise, radio and TV signal interference (wind turbines), toxic emissions (biofuels), disruption to fish populations and watercourses (mini-hydro), land use conflicts and disturbances other to their natural habitat. [3]

\section{Conventional Energy}

Conventional energy sources are irreplaceable in a short time, which is why they 
are called non-renewable. Conventional energy sources are not environmentally friendly; because it causes air, water and soil pollution which has an impact on decreasing the level of health and living standards. The primary conventional energy sources are taken from the soil in the form of liquid (oil \& petroleum), gas (natural gas) and solid (coal \& uranium). Energy sources that exist in Indonesia currently consist of limited oil sources, sufficient natural gas sources, and abundant sources of coal, as well as geothermal energy. Oil is the main primary energy source in. [2]

\section{Renewable energy}

Renewable energy is the cleanest source of energy available on the planet. There are various types of renewable energy, but not all of them can be used in remote and rural areas. Solar Power, Wind Power, Biomass and Hydropower are the most suitable technologies for providing energy in remote and rural areas. Other renewable energies including Geothermal and Tidal Energy are technologies that cannot be done everywhere. Indonesia has abundant geothermal resources; that is, about $40 \%$ of the world's total resources. However, these sources are in specific places and are not widely distributed. Another renewable energy technology is wave power, which is still under development. [2]

Renewable energy is energy obtained from natural and continuous flow of energy that occurs in the local environment. A clear example is solar energy (sunlight) which 'persists' and 'repeats' day after day, but is clearly not constant but varies. Likewise, plants have an annual growing season, which stores energy from sunlight in its structure which is released in combustion and metabolism. With renewable energy sources, energy already passes through the environment as a current or stream, regardless of the means for intercepting and harnessing these forces. It is also possible to include energy from public waste in the definition of renewable energy, because in practice it cannot be stopped. [4]

Energy can be used but not consumed. It is a law of nature that energy is conserved. Instead of consuming it, we degrade or shuffle energy, just as we scramble a mineral resource when we process concentrated ore into metal and then dispose of the end product as we do, for example, with used aluminum cans. All of the energy we use is broken down into heat and ultimately radiated out into space. What is consumed is not energy; what can be consumed is the fact that the energy has not been randomized. The degree of energy randomization is measured by the entropy of energy. [5]

\section{Energy Utilization}

Most of the energy currently used in the world comes from non-renewable sources which represents the energy source in 2001 for the whole world and for the United States respectively. What may not be expected is that most of the renewable-capable resources (geothermal, biomass, solar and wind) make little contribution to the overall energy picture. Coal $23.0 \%$, Gas $23.2 \%$, Oil $38.9 \%, 12 \%$ of the energy used to generate electricity in the US comes from renewable sources. Of this amount, $83 \%$ came from hydroelectric power. Thus, only $2 \%$ of the total comes from renewable energy remaining. Disappointingly, so far, the contribution of solar and wind energy is very small, much less than geothermal. Most of the renewable energy comes from hydropower and partly from biomass.[5]

\section{Trash}

Garbage is a material that is wasted or disposed of from natural and human activities that do not have economic value. The definition of waste is waste as unwanted waste material after the end of a process. Waste is a human-made concept, in natural processes there is no waste, only immovable products. Garbage can exist in any phase of matter: solid, liquid, or gas. When released in the last two phases, especially gas, waste can be said to be an emission. Emission is usually linked with pollution. In human life, large amounts of waste come from industrial activities (also known as waste), for example mining, manufacturing, and consumption. Almost all industrial products will become waste at some time, with an amount of waste that is roughly the same as the amount of consumption. [2]

Waste Based on the Source is household waste, agricultural waste, office waste, corporate waste, hospital waste, market waste, and others. Meanwhile, waste based on its nature is natural waste, human waste, and consumption waste. [2]

Municipal Solid Waste Management (MSW) is a significant contributor to Green House Gas (GHG) emissions and especially waste disposal in landfills produces methane $(\mathrm{CH} 4)$ which has a high global warming potential. Waste management activities and especially waste disposal in landfills contribute to global GHG 
emissions by around 4\% (Bogner et al, 2007). The most common methods used for MSW, apart from landfill, include composting, recycling, mechanical-biological treatment (MBT) and waste-to-energy (WTE). However, disposal of MSW in sanitary landfills is still the main method of waste management in many countries, both in the EU and internationally, although diversion from landfills is generally promoted and perspectives of new waste treatment technologies are also evaluated. [6] Municipal waste management seen from the point of view of local governments includes domestic waste collection activities either through door-to-door or environmental collection, transportation and disposal of waste (usually at landfills). A more environmentally oriented view of urban solid waste management includes the activities of reuse, recycling and recovery, and safe disposal of waste (in landfills or through incineration): the so-called waste hierarchy, as shown below. [7]

\section{TPA (Processing / landfills)}

Landfills are places where waste reaches the final stage in its management since it begins to emerge at the source, collection, transfer / transportation, processing and disposal. landfills is a place where waste is isolated safely so as not to cause disturbance to the surrounding environment. Because it is necessary to provide facilities and proper treatment so that security can be achieved properly. So far, there are still many wrong perceptions about landfills, which is more often than not considered as a garbage dump. [2]

\section{Waste Processing Method}

Some of the known waste treatment methods:

1. Open Dumping, Open dumping or open dumping is a simple method of disposal where waste is only spread out at one location, left open without security and left after the location is full. There are still regional governments that apply this method due to limited resources (human, financial, etc.).

2. Control Landfill, this method is an improvement from open dumping where periodically buried waste is covered with a layer of soil to reduce the potential for environmental disturbances that may arise. In its operations, waste leveling and compaction are also carried out to improve land use efficiency and landfill surface stability.

3. Sanitary Landfill. This method is a standard method used internationally where garbage closure is carried out every day so that potential disturbances can be minimized. However, it is necessary to provide infrastructure and facilities which are quite expensive for the application of this method so that until now it has only been recommended for large and metropolitan cities. [8]

\section{Total Solid (TS), Volatile Solid (VS), and Biogas Production}

Based on the test results by Tanya Mc.Donald, Gopal Achari, and Bimbola Abiola in the article "Feasibility of Increased biogas production from the co-digestion of agricultural, municipal, and agro-industrial wastes in rulal communities". By testing biogas production made from organic waste, the conversion value of organic waste into Total Solid (TS) and Volatile Solid (VS) is obtained as shown in Table 1 below. In this literature the VS value is equivalent to the resulting biogas value.

Table 2.2. Potential of Total Solid (TS), Volatile Solid (VS) and Biogas Production of organic waste

\begin{tabular}{|c|c|c|c|}
\hline $\begin{array}{c}\text { Material Type } \\
(\mathrm{kg})\end{array}$ & $\begin{array}{c}\text { Total Solid } \\
(\mathrm{TS})(\%)\end{array}$ & $\begin{array}{c}\text { Volatile Solid } \\
(\mathrm{VS})(\%)\end{array}$ & $\begin{array}{c}\text { Biogas } \\
\text { Production } \\
\left(\mathrm{m}^{2} / \mathrm{kg} \mathrm{TS}\right)\end{array}$ \\
\hline organic trash & 27,7 & 74,1 & 0,676 \\
\hline
\end{tabular}

(Source: Agung Sulistyo, 2010)

Based on the table above, the equation for calculating Total Solid, Volatile Solid, and biogas production is as follows : [8]

$\mathrm{TS}=27.7 \% \times \mathrm{Q}$

$\mathrm{VS}=74.1 \% \times \mathrm{TS}$

$\mathrm{VBS}=0.676 \times \mathrm{VS}$

Information :

$\mathrm{Q}=$ Potential Waste ( $\mathrm{kg} /$ day)

$\mathrm{TS}=$ Total Solid

VS = Volatile Solid (kg / day)

VBS $=$ Volume of biogas production (m3 / day). [8]

\section{Amount of Methane Gas}

To calculate the potential amount of methane gas produced in a landfill process.

Table 2.3 Total volume of methane gas from organic waste

\begin{tabular}{|l|l|}
\hline Biogas Production ((m3/ day) & Amount of methane gas (\%) \\
\hline
\end{tabular} VBS 60

(Source: Agung Sulistyo, 2010)

Based on the table above, the equation for calculating gas is: 
$\mathrm{VGM}=60 \% \times \mathrm{VBS}$

Information

VGM = Volume of methane gas (m3 / day)

VBS $=$ Volume of biogas production $(\mathrm{m} 3 /$ day $)$.

[8]

\section{Potential of Electrical Energy}

The potential for methane gas in $\mathrm{m} 3$ must be equalized in units of electrical energy (kWh). In the book Renewable Energy Conversion, Transmission Storage, by Bent Seronsen, $1 \mathrm{~m} 3$ of methane gas is equivalent to $6.13 \times 107$ Joules, while $1 \mathrm{kWh}$ is equivalent to $3.6 \times 107$ Joules. So that $1 \mathrm{~m} 3$ of methane gas produces electrical energy of $9.36 \mathrm{kWh}$. [9]

Table 2.4. Converting methane gas energy into electrical energy

\begin{tabular}{|l|l|}
\hline \multicolumn{1}{|c|}{ kind of energy } & \multicolumn{1}{|c|}{ energy equivalent } \\
\hline $1 \mathrm{Kg}$ methane gas & $6,13 \times 10^{7}$ Joule \\
$1 \mathrm{kWh}$ & $3,6 \times 10^{7}$ Joule \\
$1 \mathrm{~m}^{3}$ methane gas & $9,9 \mathrm{kWh}$ \\
\hline
\end{tabular}

(Source: Agung Sulistyo, 2010)

\section{Plastics and Their Types}

Various types of plastics commonly used by the public, this type of plastic contain various kinds of dangerous chemicals. There needs to be knowledge from the public to get to know the types of plastics. This code was issued by The Society of Plastic Industry in 1988 in the United States and was also adopted by institutions that developed code systems, such as ISO (International Organization for Standardization). In general, the plastic identifier: Located or located at the base, in the form of a triangle formed from three (3) arrows, inside the triangle there will be a number, as well as the name of the type of plastic under the triangle.

a) Code 1: PETE or PET (Polyethylene terephthalate)

\section{Figure 2.5 PETE OR PET}

PETE or PET (polyethylene terephthalate) is commonly used for clear / transparent / translucent plastic bottles such as mineral water bottles, juice bottles, and almost all other beverage bottles.
b) Code
2: HDPE
(High density

Figure 2.6 HDPE

HDPE (high density polyethylene) has the properties of a material that is stronger, harder, opaque and more resistant to high temperatures.

c) Code 3: V or PVC (Polyvinyl chloride)

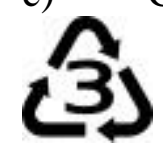

Figure $2.7 \mathrm{~V}$ or PVC

V or PVC (polyvinyl chloride) is the most difficult plastic to recycle. This plastic can be found in plastic wrap (cling wrap), and bottles. The content of PVC, namely DEHA, which is contained in the plastic wrap, can leak and enter oily food when heated.

d) Code 4: LDPE (Low density polyethylene)

\section{4.}

Figure 2.8 LDPE (Low Density Polyethylene)

LDPE (low density polyethylene) is commonly used for food containers, plastic packaging, and soft bottles. Items with code 4 are recyclable and good for items that require flexibility but are robust.

e) Code 5: PP (Polypropylene)

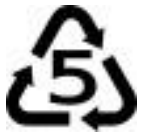

Figure 2.9 PP (Polypropylene)

$\mathrm{PP}$ (polypropylene) is the best choice for plastic materials, especially those related to food and beverages such as food storage, drinking bottles and most importantly drinking bottles for babies. Its characteristics are transparent, not clear or cloudy, and quite shiny.
f) Code 6: PS (Polystyrene)

Figure 2.10 PS (Polystyrene)

PS (polystyrene) is commonly used as a material for Styrofoam food, disposable drinking containers, etc. Polystyrene materials can leak styrine ingredients into food when the food comes in contact.

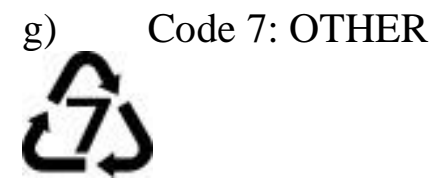

Figure 2.11 Other

There are 4 types of 7 Other plastics, namely SAN (styrene acrylonitrile), ABS (acrylonitrile butadiene styrene), PC (polycarbonate) and Nylon. Other (usually polycarbonate) can be found in food and beverage places such as sports 
drink bottles, auto parts, household appliances, computers, electronic devices, and plastic packaging.[10]

\section{Index Performance Analysis}

Performance analysis is a means of assessing the quality of a manager and measuring the added value of an active investment strategy against replicating simple indices or benchmarks. For this aspect, it is developed within the framework of market efficiency research. The validation of the efficiency theory gave rise to empirical studies, which contributed to the development of performance measurement models. [11]

\section{Optimization}

Optimization is the act of getting the best results under certain circumstances. In the design, construction and maintenance of any engineering system, engineers have to make many technological and managerial decisions at several stages. The ultimate goal of all these decisions is to minimize the effort required or to maximize the desired benefits. [12]

\section{Research Methods}

The research was conducted in the Puuwatu TPA area, Kendari City, Southeast Sulawesi Province. This research is supported by data obtained from agencies or agencies related to this research such as the Kendari City Hygiene and Gardening Office, Kendari City Statistics Agency, and several other related agencies in Kendari City and Southeast Sulawesi. This research is planned to last for 6 months starting from May 2019 to October 2020.

\section{Formulas and Equations}

a. To calculate Total Solid, Volatile Solid, and biogas production as follows (Agung Sulistyo, 2010):

$\mathrm{TS}=27.7 \% \times \mathrm{Q}$

$\mathrm{VS}=74.1 \% \times \mathrm{TS}$

$\mathrm{VBS}=0.676 \times \mathrm{VS}$

Information :

$\mathrm{Q}=$ Potential Waste ( $\mathrm{kg} /$ day)

$\mathrm{TS}=$ Total Solid

$\mathrm{VS}=$ Volatile Solid (kg / day)

VBS $=$ Volume of biogas production (m3 / day)

b. To calculate gas is:

$\mathrm{VGM}=60 \% \times \mathrm{VBS}$

Information

$\mathrm{VGM}=$ Volume of methane gas (m3 / day)

$\mathrm{VBS}=$ Volume of biogas production (m3 / day) c. Converting methane gas energy into electrical energy

\begin{tabular}{|l|l|}
\hline kind of energy & energy equivalent \\
\hline $1 \mathrm{Kg}$ methane gas & $6,13 \times 10^{7}$ Joule \\
$1 \mathrm{kWh}$ & $3,6 \times 10^{7}$ Joule \\
$1 \mathrm{~m}^{3}$ methane gas & $9,9 \mathrm{kWh}$ \\
\hline
\end{tabular}

d. The resulting pyrolysis oil

Referring to Kadir's research, 2012. Study of Utilization of Plastic Waste as a Liquid Fuel Source. [13]

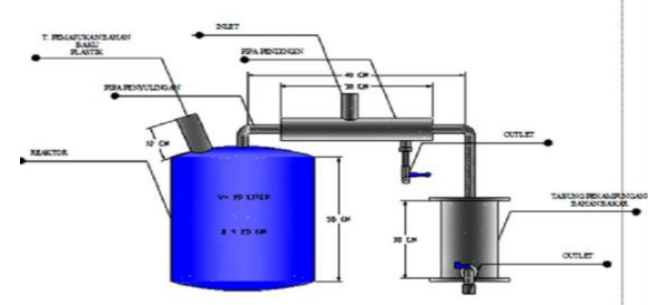

Image: Plastic Waste Treatment Plant (Kadir, 2012)

\section{Results And Discussion}

Table 5.1: Total volume of waste per month

\begin{tabular}{|l|l|}
\hline Month/year & Volume $\mathrm{m}^{3}$ \\
\hline January 2018 & $4.950,5$ \\
February 2018 & $4.410,0$ \\
March 2018 & $4.560,0$ \\
May 2018 & $6.330,5$ \\
June 2018 & $5.892,5$ \\
July 2018 & $6.523,5$ \\
\hline Total & 32.667 \\
\hline
\end{tabular}

\section{Biogas Energy Capacity from Waste Raw Materials}

Calculation of the capacity of biogas energy from waste raw materials at the Puuwatu TPA per month.

1. January 2018

For conversion from $\mathrm{m} 3$ to $\mathrm{Kg}$, multiply by 169.44, so:

$4950.5 \mathrm{~m} 3$ is equivalent to

$=4950.5 \times 169.44$

$=838,812,7 \mathrm{Kg} /$ month

$=838,812,7 / 30$ days

$=27,960,424 \mathrm{Kg} /$ day

$$
\begin{aligned}
\mathrm{TS} & =27,7 \% \times \mathrm{Q} \\
& =27,7 \% \times 27.960,424 \\
& =7.745,037448 \mathrm{~kg} \\
\mathrm{VS} & =74,1 \% \times \mathrm{TS} \\
& =74,1 \% \times 7.745,037448 \mathrm{~kg}
\end{aligned}
$$




$$
\begin{aligned}
& =5.739,0727 \mathrm{~kg} \\
\mathrm{VBS} & =0,676 \times \mathrm{VS} \\
& =0,676 \times 5.739,0727 \mathrm{~kg} \\
& =3.879,613 \mathrm{~m} 3
\end{aligned}
$$

Table 5.2: Value of Q and VBS

\begin{tabular}{|l|l|l|}
\hline \multicolumn{1}{|c|}{ month } & \multicolumn{1}{c|}{$\mathrm{Q}(\mathrm{kg} /$ day $)$} & \multicolumn{1}{c|}{$\mathrm{VBS}\left(\mathrm{m}^{3}\right)$} \\
\hline January 2018 & $27.960,424$ & $3.879,613$ \\
Feb. 2018 & $24.907,68$ & $3.456,0336$ \\
March 2018 & $25.754,88$ & $3.573,5857$ \\
May 2018 & $35.754,664$ & $4.961,0931$ \\
June 2018 & $33.280,84$ & $4.617,8414$ \\
July 2018 & $36.844,728$ & $5.112,3435$ \\
\hline TOTAL & 184503,216 & $25.600,5103$ \\
\hline
\end{tabular}

\section{Methane Gas Production}

Energy production in biogas is proportional to methane gas production

$\mathrm{VGM}=60 \% \times \mathrm{VBS}$

1. January 2018

$\mathrm{VBS}=3,879,613 \mathrm{~m} 3$

$\mathrm{VGM}=60 \% \times \mathrm{VBS}$

$$
\begin{aligned}
& =60 \% \times 3,879,613 \\
& =2,327,7678 \mathrm{~m} 3
\end{aligned}
$$

For details from January to July can be seen in the following table:

Table 5.3: Value of Methane Gas Production (VGM)

\begin{tabular}{|l|l|c|}
\hline \multicolumn{1}{|c|}{ Month/year } & \multicolumn{1}{c|}{ VBS $\left(\mathrm{m}^{3}\right)$} & VGM $\left(\mathrm{m}^{3} /\right.$ day $)$ \\
\hline January 2018 & $3.879,613$ & $2.327,7678$ \\
Feb. 2018 & $3.456,0336$ & $2.073,6202$ \\
March 2018 & $3.573,5857$ & $2.144,1514$ \\
May 2018 & $4.961,0931$ & $2.976,6559$ \\
June 2018 & $4.617,8414$ & $2.770,7048$ \\
July 2018 & $5.112,3435$ & $3.067,4061$ \\
\hline TOTAL & $25.600,5103$ & $15.360,3062$ \\
\hline
\end{tabular}

Information :

$\mathrm{VGM}=$ Methane gas production ( $\mathrm{m} 3 /$ day)

$\mathrm{VBS}=$ Volume of biogas production (m3 / day)

\section{The electrical energy produced}

From the table in theory, $1 \mathrm{~m} 3$ of methane gas is equivalent to $9.39 \mathrm{kWh}$

$\mathrm{E}=$ VGM $\times$ Fk (Correction Factor)

$=$ VGM $\times 9.39$

1. January 2018

$$
\begin{aligned}
\mathrm{VGM} & =2.327,7678 \mathrm{~m} 3 \\
\mathrm{E} & =\text { VGM } \times 9.39 \\
& =2.327,7678 \times 9.39 \\
& =21,857,7396 \mathrm{kWh}
\end{aligned}
$$

For details from January to July can be seen in the following table:

Table 5.4: VGM Value and Electrical Energy

\begin{tabular}{|l|r|r|}
\hline \multicolumn{1}{|c|}{ Month/year } & VGM $\left(\mathrm{m}^{3}\right)$ & $\mathrm{E}(\mathrm{kWh})$ \\
\hline January 2018 & $2.327,7678$ & $21.857,7396$ \\
February 2018 & $2.073,6202$ & $19.471,2933$ \\
March 2018 & $2.144,1514$ & $27.950,7905$ \\
May 2018 & $2.976,6559$ & $27.950,7905$ \\
\hline
\end{tabular}

\begin{tabular}{|l|r|r|}
\hline June 2018 & $2.770,7048$ & $26.016,9184$ \\
July 2018 & $3.067,4061$ & $28.802,9433$ \\
\hline Total & $\mathbf{1 5 . 3 6 0 , 3 0 6 2}$ & $\mathbf{1 4 4 . 2 3 3 , 2 6 6 6}$ \\
\hline
\end{tabular}

Amount of electrical energy per year:

$\mathrm{E}$ Year $=\mathrm{E}$ Total $\times 2$

$$
\begin{aligned}
& =144,233,2666 \mathrm{kWh} \times 2 \\
& =288,466,5332 \mathrm{kWh}
\end{aligned}
$$

\section{Estimated Electrical Energy}

Estimates in the daily average value from January to July 2018, the energy generated from the Puuwatu landfill in a daily average is $288,466.5332 \mathrm{kWh}$. While the energy flowing through the Mandiri Energi area, the number of houses as many as 125 houses and each house with a power of $450 \mathrm{VA}$ (MCB 2 Ampere), then the daily count used to fulfill the energy independent area is as follows:

$125 \times 360$ watts

$=45,000$ watts

$=45 \mathrm{kw} \times 24$ hours

$=1,080 \mathrm{kWh}$

So that the energy that has not been utilized from the potential in the Puuwatu landfill is:

E Useless $=288,466,5332 \mathrm{kWh}-1,080 \mathrm{kWh}$

$=287,386,5332 \mathrm{kWh}$

\section{Plastic Waste Data}

From the results of interviews and investigations with the community and plastic waste collectors in Kendari City, the following data were obtained:

- The number of collectors (plastic waste collection businesses) in Kendari City is approximately 11 collectors.

- The average collector produces 6-10 tons per month of shredded plastic.

- If averaged monthly, Kendari City produces a minimum of 66 tons per month or 792 tons per year.

Table 5.5 Results of pyrolysis oil from various types of plastics

\begin{tabular}{|l|l|c|c|}
\hline No. & \multicolumn{1}{|c|}{$\begin{array}{c}\text { Plastic Waste } \\
\text { Materials }\end{array}$} & $\begin{array}{c}\text { Massa } \\
(\mathrm{g})\end{array}$ & $\begin{array}{c}\text { Pyrolysis Oil } \\
\text { Produced } \\
\text { (Milliliter) }\end{array}$ \\
\hline 1. & PP & 500 & 470 \\
\hline 2. & HDPE & 500 & 412 \\
\hline 3. & PET & 500 & 436 \\
\hline 4. & LDPE & 500 & 375 \\
\hline \multicolumn{2}{|c|}{ Average } & 423,25 \\
\hline
\end{tabular}

\section{Pyrolysis Oil Production}

From the data on the amount of plastic waste in Kendari City and referring to Kadir's research, 2012, so that the amount of pyrolysis oil 
that can be produced from a number of plastic waste is as follows:

- Production of plastic waste (Kendari City in 2018) of 792 tons

- On average, plastic waste can produce 500 grams of $423.25 \mathrm{ml}$ of pyrolysis oil or the

equivalent of 1000 grams to produce 845.6 milliliters of pyrolysis oil.

- 1 gram = 0.001 kilogram

500 grams $\quad=500: 1000$ kilograms

$$
=0.5 \text { kilograms }
$$

- 792 tonnes $=792 \times 1000 \mathrm{~kg}$

$=792000 \mathrm{~kg}$

- $792000 \mathrm{~kg}=792000 \times 1000$ grams

$$
=792000000 \text { grams }
$$

So that the amount of plastic waste in Kendari City per year can produce pirokisis oil of:

$=792000000$ grams x 845.6

$=670428000000$ milliliters

Or,

$=\quad 670428000000 ; 1000$

$=670428000$ liters

\section{Conclusions And Suggestions}

\section{A. Conclusion}

\section{Methane Gas Utilization}

Estimates in the daily average value from January to July 2018, the energy generated from the Puuwatu landfill in a daily average is $288,466.5332 \mathrm{kWh}$. Meanwhile, the energy flowing through the Mandirin Energi area. The number of houses is 125 houses and each house with a power of $450 \mathrm{VA}$ (MCB 2 Ampere), then the daily count used to fulfill the energy independent area is as follows:

$$
\begin{aligned}
125 \times 360 \text { watts } & =45,000 \text { watts } \\
& =45 \mathrm{kw} \times 24 \text { hours } \\
& =1,080 \mathrm{kWh}
\end{aligned}
$$

So that the energy that has not been utilized from the potential in the Puuwatu landfill is:

E Useless $=288,466,5332 \mathrm{kWh}-1,080 \mathrm{kWh}$

$=287,386,5332 \mathrm{kWh}$

2. Utilization of Plastic Waste

- Production of plastic waste (Kendari City in 2018) of 792 tons

- On average, plastic waste can produce 500 grams of $423.25 \mathrm{ml}$ of pyrolysis oil or the equivalent of 1000 grams to produce 845.6 milliliters of pyrolysis oil.

So that the amount of plastic waste in Kendari City per year can produce pirokisis oil of: 670428000000 milliliters Or 670428000 liters

\section{B. Suggestions}

As a suggestion for further research, it is necessary to conduct research on the calculation of the volume of use of pyrolysis fuel oil in gasoline motorbike engines.

\section{Bibliography}

[1] Tchobanoglous, G., \& Kreith, F. (2002). Handbook of solid waste management. McGraw-Hill Education.

[2] Indonesia, T. C. E. Buku Panduan Energi yang Terbarukan. PNMP Mandiri.

[3] Laughton, M. A. (Ed.). (1990). Renewable Energy Sources: Watt Committee: report number 22 (Vol. 22). CRC Press.

[4] Twidell, J., \& Weir, T. (2015). Renewable energy resources. Routledge.

[5] Sørensen, B., Breeze, P., Suppes, G. J., El Bassam, N., Silveira, S., Yang, S. T., ... \& Storvick, T. (2008). Renewable energy focus e-Mega handbook. Academic Press.

[6] Haghi, A. K. (2010). Waste Management: Research Advances to Convert Waste to Wealth (Waste and Waste Management). Nova Science Publishers Incorporated

[7] Baud, I. S. A., Post, J., \& Furedy, C. (Eds.). (2006). Solid waste management and recycling: actors, partnerships and policies in Hyderabad, India and Nairobi, Kenya (Vol. 76). Springer Science \& Business Media.

[8] Yuspian Gunawan, et al, 2020, ICESSD 2019, October 22-23, Jakarta, Indonesia. DOI 10.4108/eai.22-10-2019.2291459

[9] Muhammad Hasbi, et al, 2020), , ICESSD 2019, October 22-23, Jakarta, Indonesia, DOI 10.4108/eai.22-10-2019.2291460 
[10] Dharini, M., \& Trihadiningrum, Y. (2010).

Studi Terhadap Timbulan Sampah Plastik Multilayer serta Upaya Reduksi yang

Dapat Diterapkan di Kecamatan Jambangan Surabaya. Jurnal Penelitian,(http://digilib. its. ac. id/public/ITS-Undergraduate-154983306100067-Paper, diakses 02 Juli 2015).

[11] Amenc, N., \& Le Sourd, V. (2005). Portfolio theory and performance analysis. John Wiley \& Sons.

[12] Rao, S. S. (2019). Engineering optimization: theory and practice. John Wiley \& Sons.

[13] Kadir, K. (2012). Kajian Pemanfaatan Sampah Plastik Sebagai Sumber Bahan Bakar cair. Dinamika: Jurnal Ilmiah Teknik Mesin, 3(2). 